\title{
Cytotoxicity and hepatoprotective attributes of methanolic extract of Rumex vesicarius $\mathrm{L}$.
}

\author{
Asha Tukappa NK, Ramesh L Londonkar*, Hanumantappa B Nayaka and Sanjeev Kumar CB
}

\begin{abstract}
Background: To evaluate the hepatoprotective potential and invitro cytotoxicity studies of whole plant methanol extract of Rumex vesicarius L. Methanol extract at a dose of $100 \mathrm{mg} / \mathrm{kg}$ bw and $200 \mathrm{mg} / \mathrm{kg}$ bw were assessed for its hepatoprotective potential against $\mathrm{CCl}_{4}$-induced hepatotoxicity by monitoring activity levels of SGOT (Serum glutamic oxaloacetic transaminase), SGPT (Serum glutamic pyruvic transaminase), ALP (Alkaline phosphatase), TP (Total protein), TB (Total bilirubin) and SOD (Superoxide dismutase), CAT (Catalase), MDA (Malondialdehyde). The cytotoxicity of the same extract on HepG2 cell lines were also assessed using MTT assay method at the concentration of 62.5, 125, 250, $500 \mu \mathrm{g} / \mathrm{ml}$.

Results: Pretreatment of animals with whole plant methanol extracts of Rumex vesicarius $L$. significantly reduced the liver damage and the symptoms of liver injury by restoration of architecture of liver. The biochemical parameters in serum also improved in treated groups compared to the control and standard (silymarin) groups. Histopathological investigation further corroborated these biochemical observations. The cytotoxicity results indicated that the plant extract which were inhibitory to the proliferation of HepG2 cell line with IC50 value of $563.33 \pm 0.8 \mu \mathrm{g} / \mathrm{ml}$ were not cytotoxic and appears to be safe.
\end{abstract}

Conclusions: Rumex vesicarius L. whole plant methanol extract exhibit hepatoprotective activity. However the cytotoxicity in HepG2 is inexplicable and warrants further study.

Keywords: Rumex vesicarius L, HepG2, MDA, SOD, CAT, CCl 4 induced hepatotocixity

\section{Background}

Liver is the largest glandular organ of the body which not only performs physiological functions but also protects our body from various injurious substance and toxic metabolic byproducts [1]. Inspite of tremendous scientific advancement in the field of hepatology in recent year liver diseases constitute a major problem of worldwide proportions. Jaundice and hepatitis are two major hepatic disorders that account for a high death rate [2]. Liver diseases are mainly caused by toxic chemicals, excess consumption of alcohol, infections and autoimmune disorders [3]. Exposure of the liver to the free radicals derived from some xenobiotic and drugs leads to oxidative stress, which is recognized to be an important factor responsible for liver injury or be involved in the pathogenesis of liver disorder $[4,5]$. Most of hepatotoxic chemicals damage liver cells mainly by inducing

\footnotetext{
* Correspondence: Iondaonkarramesh53@gmail.com

Department of Biotechnology, Gulbarga University, Gulbarga, Karnataka 585106, India
}

lipid peroxidation and other oxidative damage [3]. In oxidation process, highly reactive and harmful chain reactions of oxygen species are generated, causing damage to living organisms. The oxygen centered free radicals and other reactive oxygen species (ROS), which are continuously produced, has resulted in cell death or tissue damage. This oxidation damage caused by free radical is related to pathogenesis of many chronic degenerative diseases like cancer, diabetes, neurodegenerative diseases, atherosclerosis, cirrhosis, malaria and Acquired immune deficiency syndrome (AIDS) [6]. Hence, antioxidants may play a role in inhibiting the liver injury induced during cell damage and attribute to the hepatoprotection [7].

Antioxidant is a molecule which terminates the chain reaction by removing free radical intermediate. However plants and animals maintain complex system of multiple types of antioxidants. And also the natural plant based antioxidants have played an important role in the maintence of human health for past three decades [8]. There are a number of medicinal preparations in ayurveda that 
are recommended for the treatment of liver disorders [9]. Inspite of tremendous advances in modern medicine there are no effective and reliable drugs available that can stimulate liver function, offer protection to the tissue damage and help to regenerate cells [10].

Food rich in natural antioxidants have been proposed as a tool to prevent and cure liver damage [11]. The plants belonging to Polygonaceae family are generally a rich source of substances of phytochemical interest. Number of plants from this family is used in traditional system of medicine [12]. From the large list of various plants of Polygonaceae family we have selected Rumex vesicarius Linn. The review of literature showed that there are so many important phytoconstituents present in the various parts of the Rumex vesicarius and they are responsible for some important biological activities like antimicrobial activity, antitumor activity, wound healing and anti-inflammatory [13].

Rumex vesicarius Linn. is a branched succulent herb which belongs to the family Polygonaceae and is distributed in India. The whole plant is medicinally important and cures several diseases thus traditionally used as asperients, diuretic and cooling agent. The plant juice is useful in curing stomach heat, toothache, checks nausea and promotes appetite. Fruits are asperients and diuretic, eaten fresh against Jaundice, hepatic conditions, constipation and indigestion, rosted seeds are prescribed in dysentery [14,15].

Keeping these folkloric claims and reports in view, the present study is attempted to evaluate the possible hepatoprotective and antioxidant effect of methanolic extract of Rumex vesicarius Linn. in $\mathrm{CCl}_{4}$ induced hepatotoxicity in rats and cytotoxic effect on HepG2 cell lines.

\section{Result and discussion}

The present study is attempted to demonstrate the role of hepatoprotective activity of whole plant methanol extract of Rumex vesicarius $\mathrm{L}$. in $\mathrm{CCl}_{4}$ induced hepatotoxicity at different dose (100 $\mathrm{mg}$ and $200 \mathrm{mg} / \mathrm{kg} \mathrm{bw})$ and Cytotoxic activity on HepG2 cell lines.

\section{Hepatoprotective activity \\ Body and organ weight}

Organ weight and body weight decrease is an indication of organ injury. Organ weight changes have long been accepted as a sensitive indicator of chemically induced changes to organs. In toxicological experiments, comparison of organ weights between treated and untreated groups of animals have conventionally been used to evaluate the toxic effect of the test drug $[16,17]$. From the data presented in Table 1, it could be noticed that the body weight and the organ (liver and kidney) weight differed significantly between the $\mathrm{CCl}_{4}$ treated group and the normal control group. However, pretreatment of Rumex vesicarius $\mathrm{L}$. have reduced the effect of $\mathrm{CCl}_{4}$ on rat's body weight and organ weight.

\section{Food and water intake}

The amount of water and food intake with the animals treated with vehicle and silymarin were normal and there was no significant difference found between these groups over the period of treatment (Figures 1 and 2). The animals administrated with $\mathrm{CCl}_{4}$ (toxic group), failed to eat and drink normally when compared to vehicle and silymarin treated groups. However pretreatment of methanol extract of Rumex vesicarius $\mathrm{L}$. reduced the effect of $\mathrm{CCl}_{4}$ on food and water consumption. These results are in agreement with the work carried out by Nirwane [18]. They investigated possible hepatoprotective effect of Piper nigrum using $\mathrm{CCl}_{4}$ induced hepatotoxicity and reported that pretreatment of methanol extract reduced the effect of $\mathrm{CCl}_{4}$ on food and water consumption.

\section{Hepatotoxicity assessment}

Liver is a key organ regulating homeostasis in body. It also plays a major role in detoxification and excretion of many endogenous and exogenous compounds and injury of its function may lead to several implications on human health [19]. It has been reported that hepatotoxic chemicals, in general, release free radicals (ROS, RNS), which act on hepatic cells, especially in the liver parenchyma cells [20]. The hepatic parenchyma cells are the production site for various enzymes, bile salts and bile pigments etc. Damage caused by hepatotoxin, increases the level of liver enzymes. Liver damage induced by $\mathrm{CCl}_{4}$ is commonly used model for the screening of hepatoprotective drugs. Thus in the present study $\mathrm{CCl}_{4}$, a hepatotoxin is used to induce acute liver damage. Alkaline phosphate is a membrane bound glycoprotein enzyme related to the functioning of hepatocytes and increase in its activity is due to the increased synthesis in presence of biliary pressure. However protection of hepatocytes and stabilization of plasma membrane against the damage caused by hepatotoxin is indicated by decrease in the levels of transaminase and also reduction of alkaline phosphatase levels with concurrent depletion of raised bilirubin levels suggests the stability of the biliary function during injury with $\mathrm{CCl}_{4}[21]$.

The rise in serum levels of SGOT, SGPT, ALP, TB and $\mathrm{TP}$, has been attributed to the damaged structural integrity of the liver, because they are cytoplasmic in location and released into circulation after cellular damages [22]. When rats were treated with carbon tetrachloride it induces hepatotoxicity by metabolic activation, therefore, it selectively causes toxicity in liver cells maintaining seminormal metabolic function. Carbon tetrachloride is metabolically activated by the cytochrome P-450 dependent mixed oxidase in the endoplasmic reticulum to form trichloromethyl free radical $\left(\mathrm{CCl}_{3}\right)$ which combined with cellular lipids and proteins in the presence of oxygen to induce lipid per-oxidation [23-25]. These result in change 
Table 1 Effect of methanolic extract of Rumex vesicarius L. on body weight and organ weight compared to silymarin in liver damaged rats

\begin{tabular}{|c|c|c|c|c|c|c|}
\hline \multirow[t]{3}{*}{ Groups } & \multirow[t]{3}{*}{ Dosing } & \multicolumn{2}{|c|}{ Body weight } & \multicolumn{2}{|c|}{ Relative organ weight } & \\
\hline & & \multirow[t]{2}{*}{ Before } & \multirow[t]{2}{*}{ After } & \multirow[t]{2}{*}{ Liver } & \multicolumn{2}{|l|}{ Kidney } \\
\hline & & & & & Right side & Left side \\
\hline Group I & 1\%Tween 805 ml/kg bw.p.o & $112 \pm 6.23$ & $116 \pm 8.164$ & $4.656 \pm 0.322$ & $0.442 \pm 0.015$ & $0.449 \pm 0.023$ \\
\hline Group II & CCl4 $1.5 \mathrm{ml} / \mathrm{kg}$ bw.i.p & $119 \pm 8.34$ & $120 \pm 10.80$ & $4.163 \pm 0.22$ & $0.425 \pm 0.013$ & $0.405 \pm 0.01$ \\
\hline Group III & Silymarin 50 mg/kgbw.p.o & $113 \pm 10.12$ & $116 \pm 10.80$ & $4.582 \pm 0.873$ & $0.45 \pm 0.038$ & $0.452 \pm 0.029$ \\
\hline Group IV & 100 mg/kg bw.p.o & $104 \pm 8.65$ & $105 \pm 8.164$ & $4.22 \pm 0.728$ & $0.475 \pm 0.040$ & $0.413 \pm 0.028$ \\
\hline Group V & 200 mg/kgbw.p.o & $108 \pm 10.21$ & $111 \pm 10.80$ & $4.501 \pm 0.124$ & $0.450 \pm 0.016$ & $0.447 \pm 0.009$ \\
\hline
\end{tabular}

Each value represents the mean of 6 rats \pm S.E. significant at $P>0.05$, as compared with the corresponding control group.

of structure of the endoplasmic reticulum and other membrane, loss of metabolic enzyme activation, reduction of protein synthesis and loss of glucose-6-phosphatase activation, leading to liver injury [26].

The biochemical results of hepatoprotective activities of methanol extract of Rumex vesicarius L. at dose of $100 \mathrm{mg}$ and $200 \mathrm{mg} / \mathrm{kg}$ bw on rats intoxicated with carbon tetrachloride were illustrated in the Table. 2. Results showed that $\mathrm{CCl}_{4}$ induced a rise of the serum enzymes which are well known markers of hepatic injury. There is an increase in levels of SGPT (Serum glutamic pyruvic transaminase), SGOT (serum glutamic oxaloacetic transaminase), ALP (Alkaline phosphatase) with the value of $66.09 \pm 2.469,275.0 \pm 2.987,492.5 \pm 4.891 \mathrm{U} / \mathrm{L}$ respectively and TB (Total bilirubin) with $1.41 \pm 0.08 \mathrm{mg} / \mathrm{dl}$ with a significant decrease in TP (Total protein) with $4.93 \pm 0.13 \mathrm{mg} / \mathrm{dl}$ in $\mathrm{CCl}_{4}$ intoxicated rats as compared to the normal control group with the value of $43.15 \pm$ $3.832 \mathrm{U} / \mathrm{L}, 119.26 \pm 4.650 \mathrm{U} / \mathrm{L}, 440.7 \pm 7.07 \mathrm{U} / \mathrm{L}, 0.70 \pm$ $0.05 \mathrm{mg} / \mathrm{dl}, 6.39 \pm 0.35 \mathrm{mg} / \mathrm{dl}$ for SGPT, SGOT, ALP, TP and TB respectively.

However, pretreatment of Rumex vesicarius L extract (100 mg/kg bw and $200 \mathrm{mg} / \mathrm{kg} \mathrm{bw}$ ) and silymarin significantly preserved biochemical changes during $\mathrm{CCl}_{4}$ intoxification and confirmed their potential hepatoprotection activity to accelerate regeneration of parenchyma cells. There is fall down in the level of SGPT, SGOT, ALP and $\mathrm{TB}$ in the rats treated with $100 \mathrm{mg} / \mathrm{kgbw}, 200 \mathrm{mg} /$ kgbw of Rumex vesicarius extract and silymarin with the values of $62.52 \pm 2.063 \mathrm{U} / \mathrm{L}, 210.5 \pm 0.697 \mathrm{U} / \mathrm{L}, 214.3 \pm$ $2.843 \mathrm{U} / \mathrm{L}$. $0.91 \pm 0.03 \mathrm{mg} / \mathrm{dl}$.where as significant increase in TP with value of $5.03 \pm 0.28 \mathrm{mg} / \mathrm{dl}$ for $100 \mathrm{mg} / \mathrm{kg}$ bw of Rumex vesicarius and $53.03 \pm 2.95 \mathrm{U} / \mathrm{L}, 177.3 \pm 2.970 \mathrm{U} / \mathrm{L}$, $308.7 \pm 2.465 \mathrm{U} / \mathrm{L}, 0.98 \pm 0.04 \mathrm{mg} / \mathrm{dl}, 5.79 \pm 0.23 \mathrm{mg} / \mathrm{dl}$ of SGPT, SGOT, ALP , TB, TP respectively for high dose (200 $\mathrm{mg} / \mathrm{kgbw}$ ) of Rumex vesicarius L. which are in coordination with the results obtained for silymarin with the values of $45.96 \pm 2.029 \mathrm{U} / \mathrm{L}, 132.0 \pm 0.653 \mathrm{U} / \mathrm{L}, 275.3 \pm 3.150 \mathrm{U} / \mathrm{L}$ for SGPT, SGOT, ALP respectively and $0.86 \pm 0.04 \mathrm{mg} / \mathrm{dl}$, $5.52 \pm 0.36 \mathrm{mg} / \mathrm{dl}$ for TB and TP respectively.

The elevated serum protein level suggested the stabilization of endoplasmic reticulum leading to an increase in protein synthesis that enhanced hepatocyte regeneration [27]. On the other hand reduction in the ALP level with concurrent depletion of raised bilirubin level suggested the stability of the biliary function.
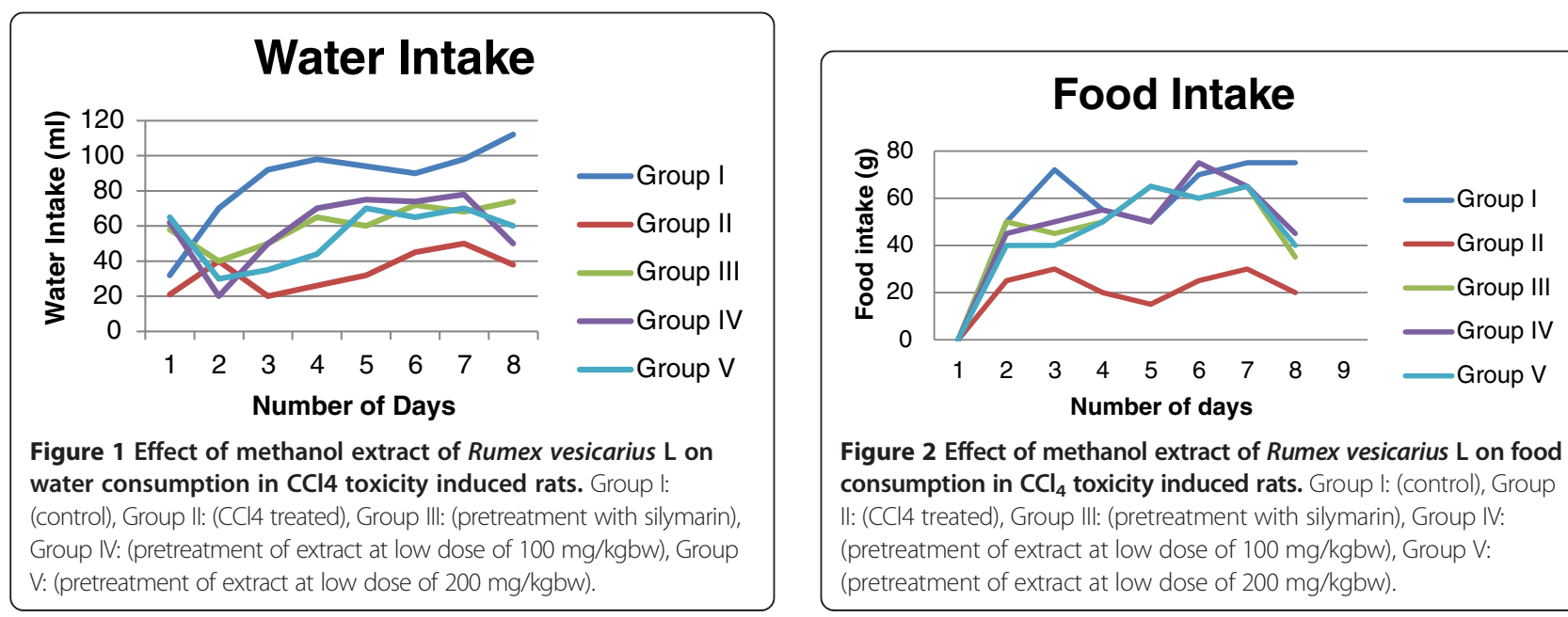

Figure 2 Effect of methanol extract of Rumex vesicarius $L$ on food consumption in $\mathrm{CCl}_{4}$ toxicity induced rats. Group I: (control), Group II: (CCl4 treated), Group III: (pretreatment with silymarin), Group IV: (pretreatment of extract at low dose of $100 \mathrm{mg} / \mathrm{kgbw}$ ), Group V: (pretreatment of extract at low dose of $200 \mathrm{mg} / \mathrm{kgbw}$ ). 
Table 2 Effect of methanolic extract of Rumex vesicarius L on plasma enzymes (SGOT, SGPT, ALP), Cholesterol, total bilirubin (T.B) and total protein (T.P) compared to silymarin in liver damaged rats

\begin{tabular}{lllllll}
\hline Groups & Dosing & SGOT (U/L) & SGPT (U/L) & ALP (U/L) & T.P (mg/dL) & T.B (mg/dL) \\
\hline Group I & 1\%Tween 80 5 ml/kg bw.p.o & $119.26 \pm 4.650$ & $43.15 \pm 3.832$ & $440.7 \pm 7.07$ & $6.39 \pm 0.35$ & $0.70 \pm 0.05$ \\
Group II & CCl4 1.5 ml/kg bw.i.p & $275.0 \pm 2.987$ & $66.09 \pm 2.469$ & $492.5 \pm 4.891$ & $4.93 \pm 0.13$ & $1.41 \pm 0.08$ \\
Group III & Silymarin 50 mg/kgbw.p.o & $132.0 \pm 0.653$ & $45.96 \pm 2.029$ & $275.3 \pm 3.150$ & $5.52 \pm 0.36$ & $0.86 \pm 0.04$ \\
Group IV & 100 mg/kg bw.p.o & $210.5 \pm 0.697$ & $62.52 \pm 2.063$ & $214.3 \pm 2.843$ & $5.03 \pm 0.28$ & $0.91 \pm 0.03$ \\
Group V & 200 mg/kgbw.p.o & $177.3 \pm 2.970$ & $53.03 \pm 2.95$ & $308.7 \pm 2.465$ & $5.79 \pm 0.23$ & $0.98 \pm 0.04$ \\
\hline
\end{tabular}

Each value represents the mean of 6 rats \pm S.E. significant at $P>0.0001$; as compared with the corresponding control group. SGOT- serum glutamic oxaloacetic transaminase, SGPT -serum glutamic pyruvic transaminase, ALP- Alkaline phosphatase, TP- Total protein TB -Total bilirubin.

\section{Antioxidant enzyme activity assay}

The body has an effective antioxidant system against free radicals and ROS induced damage in which the endogenous enzymatic and non enzymatic antioxidants such as SOD, CAT and MDA play an important role $[28,29]$. SOD and CAT antioxidant enzymes constitute a mutually supportive team of defense against ROS. The elevated level of MDA indicates excessive formation of free radicals and activation of lipid peroxidation system resulting in hepatic damage. MDA produced as byproduct by lipid peroxidation that occurs in hydrophobic core of biomembrane.

In the present study results in Table 3 proved that intoxicaton with $\mathrm{CCl}_{4}$ caused a disturbance in the antioxidant defense systems and oxidative stress as evident from a marked decreased in the antioxidant enzyme activities SOD and CAT along with increase in the MDA. The SOD and CAT values are found to be $2.23 \pm 0.15 \mathrm{U} / \mathrm{mg} \mathrm{Hb}$ and $2.27 \pm 0.10 \mathrm{U} / \mathrm{mg} \mathrm{Hb}$ compared to control group with $3.48 \pm 0.16 \mathrm{U} / \mathrm{mg} \mathrm{Hb} 2.78 \pm 0.09 \mathrm{U} / \mathrm{mg} \mathrm{Hb}$ respectively. The elevated level of MDA in $\mathrm{CCl}_{4}$ treated group with $24.2 \pm 0.76 \mathrm{nmol} / \mathrm{mg}$ compared to control group with $12.4 \pm 0.48 \mathrm{nmol} / \mathrm{mg}$, indicates excessive formation of free radicals and activation of lipid peroxidation system resulting in hepatic damage.

The pretreatment of Rumex vesicarius L.extract at the dose of $100 \mathrm{mg} / \mathrm{kgbw}, 200 \mathrm{mg} / \mathrm{kgbw}$ and silymarin at the dose of $50 \mathrm{mg} / \mathrm{kgbw}$ significantly increased SOD with $3.63 \pm 0.15 \mathrm{U} / \mathrm{mg} \mathrm{Hb}, 4.18 \pm 0.24 \mathrm{U} / \mathrm{mg} \mathrm{Hb}, 4.52 \pm 0.24$ $\mathrm{U} / \mathrm{mg} \mathrm{Hb}$ and CAT with $2.87 \pm 0.03 \mathrm{U} / \mathrm{mg} \mathrm{Hb}, 3.35 \pm$ $0.14 \mathrm{U} / \mathrm{mg} \mathrm{Hb}, 3.27 \pm 0.11 \mathrm{U} / \mathrm{mg} \mathrm{Hb}$ respectively. There is significant decline in the concentration of MDA in the rats pretreated with Rumex vesicarius L. extract of 100 $\mathrm{mg} / \mathrm{kgbw}, 200 \mathrm{mg} / \mathrm{kg}$ bw and silymarin with $17.1 \pm 0.53$ $\mathrm{nmol} / \mathrm{mg}, 14.6 \pm 0.54 \mathrm{nmol} / \mathrm{mg}, 15.3 \pm 0.67 \mathrm{nmol} / \mathrm{mg}$ respectively, indicates antilipid peroxidation effect of Rumex vesicarius L. (Table 3), also the pretreatment of Rumex vesicarius $\mathrm{L}$. effectively blocked $\mathrm{CCl}_{4}$ induced abnormal changes in the liver and activity of SOD and CAT in rats reveals that Rumex vesicarius $\mathrm{L}$. have a potent antioxidant property towards chemical induced hepatic injury.

\section{Histopathological studies}

The results of histopathological studies provided supportive evidence for biochemical analysis. Histology of liver section of normal control animal exhibit normal

Table 3 Effect of methanolic extract of Rumex vesicarius L on SOD, CAT, MDA compared to silymarin in liver damaged rats

\begin{tabular}{|c|c|c|c|c|}
\hline Groups & Dosing & SOD (U/mg Hb) & CAT (U/mg Hb) & MDA (nmol/mg) \\
\hline Group I & 1\%Tween 80 & & & \\
\hline Control & $5 \mathrm{ml} / \mathrm{kg}$ bw.p.o & $3.48 \pm 0.16$ & $2.78 \pm 0.09$ & $12.4 \pm 0.48$ \\
\hline Group ॥ & $\mathrm{CCl} 4$ & $2.23 \pm 0.15$ & $2.27 \pm 0.10$ & $24.2 \pm 0.76$ \\
\hline Toxic & $1.5 \mathrm{ml} / \mathrm{kg}$ bw.i.p & & & \\
\hline Group III & Silymarin & $4.52 \pm 0.24$ & $3.27 \pm 0.11$ & $15.3 \pm 0.67$ \\
\hline Positive control & 50 mg/kgbw.p.o & & & \\
\hline Group IV & 100 mg/kg bw.p.o & $3.63 \pm 0.15$ & $2.87 \pm 0.03$ & $17.1 \pm 0.53$ \\
\hline \multicolumn{5}{|l|}{ Low dose } \\
\hline Group V & 200 mg/kgbw.p.o & $4.18 \pm 0.24$ & $3.35 \pm 0.14$ & $14.6 \pm 0.54$ \\
\hline High dose & & & & \\
\hline
\end{tabular}

Each value represents the mean of 6 rats \pm S.E. significant at $P<0.0001$; as compared with the corresponding control group. SOD: superoxide dismutase; CAT: catalase; MDA = malondialdehyde. 
hepatic cells each with well defined cytoplasm, prominent nucleus and nucleolus and well brought central vein (Figure 3A). The $\mathrm{CCl}_{4}$ intoxicated group animals showed total loss of hepatic architecture with centrilobular hepatic necrosis, fatty changes vacuolization and congestion of sinusoids, kupffer cell hyperplasia, crowding of central vein and apoptosis (Figure 3B). Pretreatment with Rumex vesicarius $\mathrm{L}$. at the dose of $100 \mathrm{mg} / \mathrm{kgbw}$ and $200 \mathrm{mg} / \mathrm{kgbw}$ and silymarin showed protecting activity (Figure 3C-E). The methanol extract of Rumex vesicarius L. at low dose of $100 \mathrm{mg} / \mathrm{kg}$ bw. showed moderate or weak hepatoprotective activity for $\mathrm{CCl}_{4}$ injury. However the methanol extract at the high dose of $200 \mathrm{mg} / \mathrm{kg}$ bw and silymarin had shown a potential hepatoprotective activity and reduced the degenerative changes in liver. The result thus obtained is in the agreement with the work carried out by Sahreen [26]. They reported the hepatoprotective activity of methanol extract of Carissa opaca leaves on $\mathrm{CCl}_{4}$ induced damage in rat.

\section{Cytotoxicity}

Plants contain almost unlimited capacity to generate compounds that fascinates researchers in the quest for new and novel chemotherapeutics [30]. The persistency search for new compounds in medicinal plant and traditional food is a realistic and promising strategy for prevention of diseases [31]. Therefore in this study Rumex vesicarius L. was evaluated for its Cytotoxicity on HepG2 (human hepatocarcinoma) cells using MTT (3-(4, 5-dimethylythiazol-2yl)-2, 5-diphenyl-2H-tetrazolium hydrobromide) assay. The ability of the cells to survive a toxic insult has been the basis of most Cytotoxicity assays.

In the present study cytotoxicity of whole plant methanol extract of Rumex vesicarius L. at different concentration $(62.5 \mu \mathrm{g} / \mathrm{ml}, 125 \mu \mathrm{g} / \mathrm{ml}, 250 \mu \mathrm{g} / \mathrm{ml}, 500 \mu \mathrm{g} / \mathrm{ml}$, and $1000 \mu \mathrm{g} / \mathrm{ml}$ ) were presented in Table 4 . The \% cytotoxicity of methanol extract of Rumex vesicarius $\mathrm{L}$. was found to be dose dependent and increases with increased concentrations. HepG2 experienced significant decrease in viability at low concentration of methanol extract of Rumex vesicarius $\mathrm{L}$. with eventual decline at highest concentration tested. The \% inhibition of cell proliferation at 62.5 $\mu \mathrm{g} / \mathrm{ml}, 125 \mu \mathrm{g} / \mathrm{ml}, 250 \mu \mathrm{g} / \mathrm{ml}, 500 \mu \mathrm{g} / \mathrm{ml}, 1000 \mu \mathrm{g} / \mathrm{ml}$ was found to be $21.57 \pm 0.7,32.68 \pm 1.0,41.69 \pm 0.6,47.92$ $\pm 0.9,70.21 \pm 0.6$ respectively, with an IC50 value of $563.88 \pm 0.8 \mu \mathrm{g} / \mathrm{ml}$.
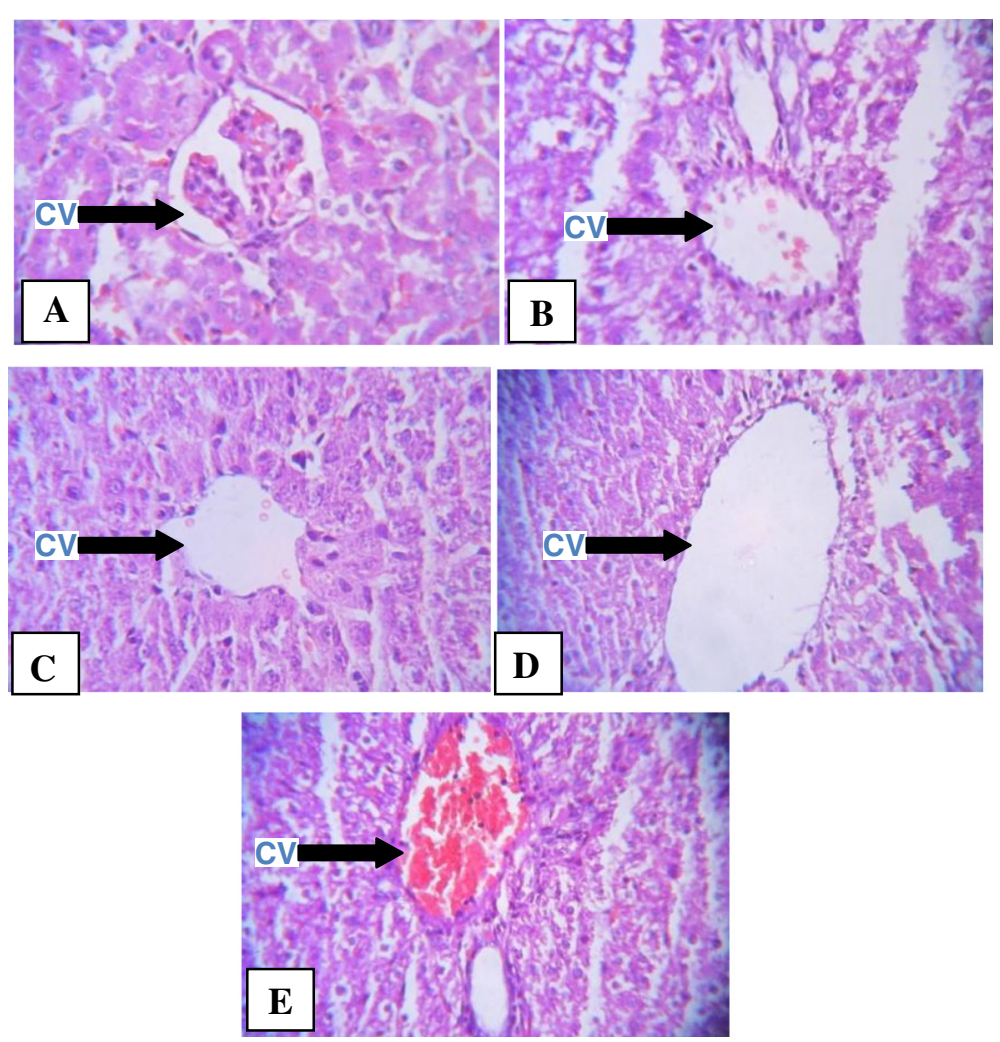

Figure 3 Effect of methanolic extract of Rumex vesicarius $\mathrm{L}$ on acute liver injury induced by $\mathrm{CCl}_{\mathbf{4}}$. A: (control): liver section with normal structure and architecture. B: (CCl4 treated): showing extensive area of necrosis, profound inflammation and congestion. C: (pretreatment with silymarin): reduced inflammation and degenerative changes. D: (pretreatment of extract at low dose of $100 \mathrm{mg} / \mathrm{kgbw}$ ): reduced inflammation, degenerative changes. $\mathbf{E}$ : (pretreatment of extract at low dose of $200 \mathrm{mg} / \mathrm{kgbw}$ ): reduced inflammation, degenerative changes. cV: central vein 


\begin{tabular}{|c|c|c|c|}
\hline SI. no & $\begin{array}{l}\text { Test conc. } \\
(\mu \mathrm{g} / \mathrm{ml})\end{array}$ & $\%$ Cytotoxicity & $\begin{array}{l}\mathrm{CTC}_{50} \\
(\mu \mathrm{g} / \mathrm{ml})\end{array}$ \\
\hline 1 & 1000 & $70.21 \pm 0.6$ & \\
\hline 2 & 500 & $47.92 \pm 0.9$ & \\
\hline 3 & 250 & $41.69 \pm 0.6$ & $563.33 \pm 0.8$ \\
\hline 4 & 125 & $32.68 \pm 1.0$ & \\
\hline 5 & 62.5 & $21.57 \pm 0.7$ & \\
\hline
\end{tabular}

A study carried out by Patel evaluated that methanolic extract of S. nigrum fruits has potential activity on HeLa cell and lesser effect on Vero cell. So, the drug has considerable anticancer activity on cervical cancer [32]. Wang et al. showed antitumor effects of methanolic extract of S. nigrum fruits on U266 cells [33]. During Wang et al.'s search for new anti-tumor agents, the ethanolic extract of fruits of C. pepo was observed to exhibit a significant dose-dependent inhibitory effect against HeLa cell growth [34].

Magdalena [35] investigated in vitro screening of cytotoxic activities of ethanol extract from roots, leaves and fruits of six Rumex species: $R$. acetosa L., $R$. acetosella L., $R$. confertus Willd., $R$. crispus L., $R$. hydrolapathum Huds. and R. obtusifolius L. on leukemic 1301 and EOL1 cell lines. There is however sources confirming strong cytotoxic properties of the compounds that have been isolated from Rumex acetosa against tumor cell lines. Chrysophanol, Physcion, emodin and emodin-8-O- $\beta-\mathrm{D}-$ glucopiranoside were isolated from methanol extract of Rumex acetosa. They showed high cytotoxicity activity against 5 human tumor cell lines A549 lung cancer, overian Sk-OV-3, Central nerous system XF 498, Intestines HCT-15 and MEC-2 melanoma.

When examining cytotoxicity properties of Dock species, two herbal preparation Essiac ${ }^{\circ}$ and Flor Essenc ${ }^{\circ}$ which include herb of Rumex acetosella. It has been also proved that those herbal tonic induced proliferation of T47D, MDA-MB-231 and MDA-MB-436 breast cancer cell lines [36-38]. Recent studies have confirmed the properties of many cytotoxic compounds from roots of Rumex crispus, responsible for killing cells lines DLD-1 (human colon adenocarcinoma cell line) [39].

In the present study the methanol extract showed invitro cytotoxicity and invivo hepatoprotective potential. As per our earlier findings, the methanol extract consist of many secondary metabolites like phenols, flavonoids, alkaloids, glycosides. The cytotoxicity and hepatoprotective attributes may be due to these different secondary metabolites which may have a different pharmacological activity.

\section{Conclusion}

The present study demonstrated the protective activity of Rumex vesicarius $\mathrm{L}$. against $\mathrm{CCl}_{4}$ induced hepatotoxicity might be due to its antioxidant potential. The hepatoprotective role of Rumex vesicarius L. extract was found to be comparable with silymarin which might be due to the presence of flavonoid providing a new way to develop potential hepatoprotective drugs. The Rumex vesicarius $\mathrm{L}$. allows us to conclude that extracts is good candidates for further studies of activity-monitored fractionation to identify their active components. Cytotoxicity study of methanol extract in HepG2 is however inexplicable and warrants further study.

\section{Methods}

\section{Plant material}

The plant Rumex vesicarius. Linn was collected from village Khusnoor, Gulbarga district, Karnataka in the month of July- August and authenticated by Department of Botany, Gulbarga University, Gulbarga. The Voucher specimen was submitted at Department of Botany with the reference No. HGUG-5012.

\section{Preparation of extract}

The powdered crude drug of Rumex vesicarius L. was successively extracted with petroleum ether, chloroform and methanol by soxhlet method. The extract was filtered and concentrated to dryness at room temperature. Our earlier qualitative chemical investigation of petroleum ether, chloroform and methanol extract reveals, the presences of secondary metabolites in methanol extract are high [40]. Thus methanol extract was selected for further study.

\section{Hepatoprotective activity}

\section{Drugs and chemicals}

Silymarin was purchased from Microlabs Limited, Goa. All other chemicals used in this study were of analytical grade.

\section{Experimental animals}

Male albino rats of Wistar strain weighing between 100 and $130 \mathrm{~g}$ (8 weeks old) were purchased from the Animal House Colony of the Luqman Pharmacy College, Gulbarga. The animals were housed in polypropylene cages and maintained at $25 \pm 2^{\circ} \mathrm{C}$ under $14 / 10 \mathrm{~h}$ dark and light cycle. They were allowed free access to standard pellet diet and water ad libitum. The animals were acclimatized for one week under laboratory conditions. Ethical clearance for handling the animals was obtained from the ethical committee constituted for the purpose (CPCSEA Reg. No. 34800/2001).

\section{Animal dose}

Based on our earlier studies of acute and short term toxicities the appropriate dose for preclinical study was 
calculated and found to be $100 \mathrm{mg} / \mathrm{kg}$ body weight (low dose) and $200 \mathrm{mg} / \mathrm{kg}$ body weight (high dose) (communicated data).

\section{Experimental design}

Rats were divided into 5 groups, each with 6 animals:

Group I Control (vehicle): Received 1\% v/v Tween-80 in distilled water ( $5 \mathrm{ml} / \mathrm{kg}$ body weight, p.o.) single daily dose for 6 consecutive days.

Group II ( $\mathrm{CCl}_{4}$ induced): Received 1\% v/v Tween-80 in distilled water ( $5 \mathrm{ml} / \mathrm{kg}$ body weight, p.o.) single daily dose for 6 consecutive days.

Group III (standard): Received standard drug Silymarin (100 mg/kg body weight p.o.) single daily dose for 6 consecutive days.

Group IV (Low dose): Received methanol extract of Rumex vesicarius $\mathrm{L}$. (100 mg/kg body weight, p.o.) single daily dose for 6 consecutive days.

Group V (High dose): Received methanol extract

Rumex vesicarius L. (200 mg/kg body weight, p.o.)

single daily dose for 6 consecutive days.

Groups from II to $\mathrm{V}$ have received $\mathrm{CCl}_{4}$ in olive oil $(1: 1 \mathrm{v} / \mathrm{v}, 1.5 \mathrm{ml} / \mathrm{kg}$ body weight i.p.) single dose on the 7 th day. The quantity of food and water consumed was recorded for each group of animals during the course of the experiment. The body a weight of each rat was recorded on the 1st day and on 8th day, mean body weights were calculated. Liver weight and kidney weight were also determined to know the effect of drug on normal morphology and physiology of rats. Organ index was calculated according to the formula: (liver or kidney weight/body weight) $\times 100 \%$.

\section{Sample collection}

All rats were sacrificed by cervical decapitation separately after 24 hrs of the last treatment on 8th day. Blood samples of each group were collected into dry sterilized tubes and centrifuged at $3000 \mathrm{r} / \mathrm{min}$. for $10 \mathrm{~min}$ to obtain clear serum. Liver and Kidney were quickly excised, rinsed in cold saline, blotted, and weighed. A part of liver was freshly used for assay of malondialdehyde (MDA) and another part is used for histopathological examination.

\section{Hepatotoxicity assessment}

The hepatic enzymes SGOT and SGPT were used as the biochemical indicators for the acute liver injury. The serum SGOT, SGPT, ALP, TB and TP activities were determined by using a commercial diagnostic kit Biocompare, BioVision, Thermo scientific and Biooscientific Max discovery.

\section{Antioxidant enzyme activity assay Preparation of erythrocyte lysate}

The packed cells, after separation of serum, were washed with a physiological saline 3 times and lysed with hypotonic phosphate buffer, $\mathrm{pH}$ 7.4. The hemolysate was separated by centrifuging at $2500 \mathrm{r} / \mathrm{min}$ for $15 \mathrm{~min}$ at $4^{\circ} \mathrm{C}$ and used for assay of erythrocyte superoxide dismutase (SOD) and catalase (CAT) activities.

\section{Superoxide dismutase (SOD)}

This method is well described by McCord and Fridovich and can be applied for determination of antioxidant activity of a sample. It is estimated in the erythrocyte lysate prepared from the $5 \% \mathrm{RBC}$ suspension. To $50 \mathrm{lL}$ of the lysate, $75 \mathrm{mM}$ of Tris- $\mathrm{HCl}$ buffer (pH 8.2), $30 \mathrm{mM}$ EDTA and $2 \mathrm{mM}$ of pyrogallol are added. An increase in absorbance is recorded at $420 \mathrm{~nm}$ for $3 \mathrm{~min}$ by spectrophotometer. One unit of enzyme activity is $50 \%$ inhibition of the rate of autooxidation of pyrogallol as determined by change in absorbance $/ \mathrm{min}$ at $420 \mathrm{~nm}$. The activity of SOD is expressed as units/mg protein [41].

\section{Catalase (CAT)}

Catalase activity can be determined in erythrocyte lysate using Aebi's method [42]. Fifty micro liter of the lysate is added to a cuvette containing $2 \mathrm{~mL}$ of phosphate buffer (pH 7.0) and $1 \mathrm{~mL}$ of $30 \mathrm{mM} \mathrm{H}_{2} \mathrm{O}_{2}$. Catalase activity is measured at $240 \mathrm{~nm}$ for $1 \mathrm{~min}$ using spectrophotometer. The molar extinction coefficient of $\mathrm{H}_{2} \mathrm{O}_{2}, 43.6 \mathrm{M} \mathrm{cm} \_1$ was used to determine the catalase activity. One unit of activity is equal tol mmol of $\mathrm{H}_{2} \mathrm{O}_{2}$ degraded per minute and is expressed as units per milligram of protein.

\section{Lipid Peroxidation (LPO) assay}

The liver tissues were homogenized in 10\% ice-cold phosphate buffered saline $(0.1 \mathrm{M}, \mathrm{pH} 7.4, \mathrm{w} / \mathrm{v})$ and centrifuged at $2000 \mathrm{r} / \mathrm{min}$ for $30 \mathrm{~min}$; the supernatant was used for the assay of MDA.

LPO is an autocatalytic process, which is a common consequence of cell death. This process may cause peroxidative tissue damage in inflammation, cancer and toxicity of xenobiotics and aging. Malondialdehyde (MDA) is one of the end products in the lipid peroxidation process. Malondialdehyde (MDA) is formed during oxidative degeneration as a product of free oxygen radicals, which is accepted as an indicator of lipid peroxidation. This method described by Ohkawa is as follows: The tissues are homogenized in $0.1 \mathrm{M}$ buffer $\mathrm{pH} 7.4$ with a Teflonglass homogenizer. LPO in this homogenate is determined by measuring the amounts of malondialdehyde (MDA) produced primarily. To tissue homogenate $(0.2 \mathrm{~mL}), 0.2 \mathrm{~mL}$ of $8.1 \%$ sodium dodecyl sulfate (SDS), $1.5 \mathrm{~mL}$ of $20 \%$ acetic acid and $1.5 \mathrm{~mL}$ of $8 \%$ TBA are added. The volume of the mixture is made 
up to $4 \mathrm{~mL}$ with distilled water and then heated at $95^{\circ} \mathrm{C}$ on a water bath for $60 \mathrm{~min}$ using glass balls as condenser. After incubation the tubes were cooled to room temperature and final volume was made to $5 \mathrm{~mL}$ in each tube. Five mL of butanol: pyridine (15:1) mixture is added and the contents are vortexed thoroughly for $2 \mathrm{~min}$. After centrifugation at $3000 \mathrm{rpm}$ for $10 \mathrm{~min}$, the upper organic layer is taken and its OD is taken at $532 \mathrm{~nm}$ against an appropriate blank without the sample. The levels of lipid peroxides can be expressed as moles of thiobarbituric acid reactive substances (TBARS)/mg protein using an extinction coefficient of $1.56 \cdot 10$ 5ML cm_1 [43].

\section{Histopathological studies}

The liver tissues were removed from the animals and immediately fixed in $10 \%$ formalin. Subsequent processing included dehydrating in increasing ethanol solutions (50-100\%), clearing in xylene and embedding in paraffin. Sections $(4-5 \mu \mathrm{m})$ were prepared and then stained with Haematoxylin/Eosin dye for photo microscopic observation.

\section{Cytotoxicity}

\section{Chemicals}

3-(4,5-dimethyl thiazol-2-yl)-5-diphenyl tetrazolium bromide (MTT), Fetal Bovine serum (FBS), Phosphate Buffered Saline (PBS), Dulbecco's Modified Eagle's Medium (DMEM) and Trypsin were obtained from Sigma Aldrich Co, St Louis, USA. EDTA, Glucose and antibiotics from Hi-Media Laboratories Ltd., Mumbai. Dimethyl Sulfoxide (DMSO) and Propanol from E. Merck Ltd., Mumbai, India.

\section{Cell lines and culture medium}

HepG2 (human hepatocarcinoma) cell lines were procured from National Centre for Cell Sciences (NCCS), Pune, India. Stock cells were cultured in DMEM supplemented with $10 \%$ inactivated Fetal Bovine Serum (FBS), penicillin $(100 \mathrm{IU} / \mathrm{ml})$, streptomycin $(100 \mu \mathrm{g} / \mathrm{ml})$ and amphotericin B $(5 \mu \mathrm{g} / \mathrm{ml})$ in an humidified atmosphere of $5 \% \mathrm{CO}_{2}$ at $37^{\circ} \mathrm{C}$ until confluent. The cells were dissociated with TPVG solution $(0.2 \%$ trypsin, $0.02 \%$ EDTA, $0.05 \%$ glucose in PBS). The stock cultures were grown in $25 \mathrm{~cm}^{2}$ culture flasks and all experiments were carried out in 96 microtitre plates (Tarsons India Pvt. Ltd., Kolkata, India).

\section{Preparation of test solution}

For Cytotoxicity studies, weighed extract was dissolved in distilled DMSO and volume was made up with DMEM supplemented with $2 \%$ inactivated FBS to obtain a stock solution of $1 \mathrm{mg} / \mathrm{ml}$ concentration and sterilized by filtration. Serial two fold dilutions were prepared from the stock to carry out cytotoxic studies.

\section{MTT assay}

The monolayer cell culture was trypsinized and the cell count was adjusted to $1.0 \times 10^{5}$ cells $/ \mathrm{ml}$ using DMEM containing $10 \%$ FBS. To each well of the 96 well microtitre plate, $0.1 \mathrm{ml}$ of the diluted cell suspension (approximately 10,000 cells) was added. After $24 \mathrm{~h}$, when a partial monolayer was formed, the supernatant was flicked off, washed the monolayer once with medium and $100 \mu \mathrm{l}$ of different test concentrations of test drugs were added on to the partial monolayer in microtitre plates. The plates were then incubated at $37^{\circ} \mathrm{C}$ for 3 days in $5 \% \mathrm{CO}_{2}$ atmosphere, and microscopic examination was carried out and observations were noted every $24 \mathrm{~h}$ interval. After $72 \mathrm{~h}$, the drug solutions in the wells were discarded and $50 \mu \mathrm{l}$ of MTT in PBS was added to each well. The plates were gently shaken and incubated for $3 \mathrm{~h}$ at $37^{\circ} \mathrm{C}$ in $5 \% \mathrm{CO}_{2}$ atmosphere. The supernatant was removed and $100 \mu \mathrm{l}$ of propanol was added and the plates were gently shaken to solubilize the formed formazan. The absorbance was measured using a microplate reader at a wavelength of $540 \mathrm{~nm}$. The percentage growth inhibition was calculated using the following formula and concentration of test drug needed to inhibit cell growth by $50 \%\left(\mathrm{CTC}_{50}\right)$ values is generated from the dose-response curves for each cell line [44].

$\%$ Growth inhibition $=100-[$ Mean OD of individual test group/Mean OD of control group $\times 100]$.

\section{Statistical analysis}

Statistical analysis was performed using Graph pad (version 6.04).The data were expressed as means $\pm S D$, and significant differences were determined by One-way analysis of Variance (ANOVA) followed with Duncan's multiple range tests. A $p$-value of less than 0.01 was considered statistically significant.

\section{Abbreviations \\ p.o: Per os; i.p: Intraperitoneal; bw: Body weight; v/v: Volume/volume; w/v: Weight/volume.}

\section{Competing interests}

The authors declare that they have no competing interests.

\section{Authors' contributions}

$R L$, the corresponding author has generated the idea for the experiment and has critically examined and corrected the manuscript. AT, the first author has conducted the experimental work and written the manuscript. Other authors HBN and SB have helped during the experimental work and in interpretation of the results. All authors read and approved the final manuscript.

\section{Acknowledgments}

The authors are thankful to University Grant Commission New Delhi (India) for providing financial support to carry out this research work under the scheme of Rajeev Gandhi National Fellowship (UGC-RGNF). The authors are also thankful to Gulbarga University, Gulbarga, for providing all the necessary facilities to carry out this research. 
Received: 30 August 2014 Accepted: 4 March 2015

Published online: 25 March 2015

\section{Reference}

1. Maher JJ. Exploring alcohol's effects on liver function. Alcohol health Res World. 1997;21:5-12.

2. Shahani S. Invivo evaluation of hepatoprotective efficacy of APCL-polyherbal formulation in rats. Indian Drugs. 1999;36:628-31.

3. Dianzani MU, Muzio G, Biocca ME, Canuto RA. Lipid peroxidation in fatty liver induced by caffeine in rats. Int J Tissue React. 1991;13:79-85.

4. Jaeschke $H$. Reactive oxygen and mechanism of inflammatory liver injury: present concepts. J Gastroenterol Hepatol. 2011;26:173-9.

5. Kaplowitz N. Biochemical and cellular mechanism of toxic liver injury. Semin Liver Dis. 2002;22:137-44.

6. Nagler R, Reznick A, Shafir Y, Shehadeh N. Free radical related effects and antioxidants in saliva and serum of adolescents with type-I diabetes mellitus. Arch Oral Biol. 2002:40:156.

7. Slater TF. Free radical mechanisms in tissue injury. J Biochem. 1984;222:1-15.

8. Devasagayam TPA, Tilak JC, Boloor KK. Review: free radicals and antioxidants in human health: current status and future prospects. J Assoc Physicians India. 2004;52:794-804

9. Chatterjee TK. Medicinal plants with hepatoprotective properties in herbal opinions. 3rd ed. Calcutta: Books and Allied (P) Ltd; 2000. p. 79-84.

10. Venukumar MR, Latha MS. Hepatoprotective effect of the methanolic extract of Curculingo orchiodes in $\mathrm{CCl}_{4}$ treated male rats. Indian J Pharmacol. 2002;34:269-75.

11. Morisco F, Vitaglione P, Amoruso D, Russo B, Fogliano V, Caporaso N. Food and liver health. Mol Asp Med. 2008;29:144-50.

12. Rao KNV, Sunitha CH, David B, Sandhya S, Mahesh V. A study of the nutraceuticals from the genus Rumex. J Drugs Med. 2011;3(1):76-88.

13. Mona A, AbouElfotoh Khaled AS, Kevin PA, Abdelaaty AS Magada TI, Nevein MA, Nahal AA, et al. Lipophilic constituents of Rumex vesicarius $L$ and Rumex dentatus L. Antioxidants. 2013:2:167-80.

14. Yusuf MJ, Begum MN, Hoque, JU Chowdhury: Medicinal plants of Bangladesh, BCSIR Chittagong-4220 2009,749

15. Asha T, Ramesh LL. Evalution of antibacterial and antioxidant activities of different methanol extract of Rumex vesicarius $\mathrm{L}$. Am J Drug Discov Dev. 2013;3(2):72-83.

16. Peters JM, Boyd EM. Organ weights and water levels of the rat following reduced food intake. J Nutr. 1966;90(4):354-60.

17. Pfeiffer CJ. A mathematical evaluation of the thymic weight parameter. Toxicol Appl Pharmacol. 1968;13(2):220-7.

18. Nirwane AM, Bapat AR. Effect of methanol extract of piper nigrum fruits in ethanol-CCl 4 induced hepatotoxicity in wister rats. Der Pharmacia Letter. 2012;4(3):795-802.

19. Burtes CA, Ashwood ER. Textbook of clinical chemistry. Philadelphia: WB Sunders Co; 1986. p. 56.

20. Masao H, Yang XW, Migashiro H, Namba T. Inhibitory effects of monomeric and dimeric phenyl propanoids on lipid peroxidation invivo and invitro. Phytother Res. 1993;7:395-401.

21. Sallie R, Tredger JM, William R. Drugs and the liver. Part I. Testing liver function. Biopharm Drug Disp. 1991;12:251-9.

22. Recknagel Jr RO, Glende RA, Hruszkewycz MA. In: Pryor Jr EA, editor. Free radicals in biology, Vol. II. New York: Academic Press; 1976. p. 97-132.

23. Recknagel RO. A new direction in the study of carbon tetrachloride hepatotoxicity. Life Sci. 1983;33:401-8.

24. De Groot H, Noll T. The crucial role of low stedy state oxygen pressures in haloalkane free radical mediated lipid peroxidation. Biochem Pharmacol. 1986;35:15-9.

25. Gravel E, Albano E, Dianzani MU, Poli G, Slater TF. Effects of carbon tetrachloride on isolated rat hepatocytes: inhibition of protein and lipoprotein secretion. Biochem J. 1979;178:509-12.

26. Sahreen S, Khan MR, Khan RA. Hepatoprotective effects of methanol extract of Carissa opaca leaves on CCl4-induced damage in rat. BMC Complem Altern Med. 2011;11:48.

27. Chow CK. Nutritional influence on cellular antioxidant defence systems. Am J Clin Nutr. 1979;32:1066-81.

28. Blokhina O, Virolainen E, Fagersted KV. Antioxidants: oxidative damage and oxygen deprivation stress: a review. Ann Bot. 2003;91:179-94.

29. Halliwell B, Chirico S. Lipid peroxidation: its mechanism, measurement and significant. Am J Clin Nutr. 1993;57:715S-24.
30. Reed JC, Pellecchia M. Apoptosis-based therapies for hematologic malignancies. Blood. 2005:106:408-41.

31. Yan-Wei H, Chun-Yu L, Chong-Min D, Wen Qian W, Zhen Lun G. Induction of apoptosis in human hepatocarcinoma SMMC-7721 cells in vitro by flavonoids from Astragalus complanatus. J Ethnopharmacol. 2009;123:293-301.

32. Patel S, Gheewala N, Suthar A, Shah A. In-vitro cytotoxicity activity of Solanum nigrumextract against Hela cell line and Vero cell line. Int J Pharm Pharmaceut Sci. 2009;1:38-46.

33. Wang DC, Pan HU, Deng XM, Xiang H, Gao HY, Cai H, et al. Cucurbitane and hexanorcucurbitane glycosides from the fruits of Cucurbita pepo $\mathrm{cV}$ dayangua. J Asian Nat Pro Res. 2007;9:525-9.

34. Wang W, Lu DP. An in vitro study of cytotoxic and antineoplastic effect of Solanum nigrum L extract on U266. Beijing Da Xue Xue Bao. 2005;37:240-4

35. Izdebska M, NatorskaChomicka D, Jagiełło-Wójtowicz E. Preliminary studies evaluating cytotoxic effect of combined treatment with Methotrexate and simvastatin on green monkey kidney cells. Acta Poloniae Pharmaceutica Drug Res. 2014;71(3):515-20.

36. Kulp KS, Montgomery JL, Nelson DO, Cutter B, Latham ER, Shattuck DL, et al. Essiac and Flor-Essence herbal tonics stimulate the in vitro growth of human breast cancer cells. Breast Cancer Res Treat. 2006;98(3):249-59.

37. Zick SM, Sen A, Feng Y, Green J, Olatunde S, Boon H. Trial of Essiac to ascertain its effect in women with breast cancer (TEA-BC). J Altern Complement Med. 2006;12(10):971-80.

38. Tai J, Cheung S, Wong S, Lowe C. In vitro comparison of Essiac and Flor-Essence on human tumor cell lines. Oncol Rep. 2004;11:471-6.

39. Kumari IS. Identification of anticancer com pounds from Rumex crispus root In: Stephen F, editor. Dissertation AAT 1444572. Nacogdoches, Texas, USA: Austin State University; 2007.

40. Ramesh LL, Asha Tukappa NK. Pharmacognostic evaluation and comparative phytochemical screening of Rumex vesicarius L. Int J Phytomed. 2013;5(2):146-53

41. McCord JM, Fridovich I. Superoxide dismutase. An enzymic function for erythrocuprein (hemocuprein). J Biol Chem. 1969;244:6049-55.

42. Aebi H. Catalase in Vitro. Method Enzymol. 1984;105:121-6.

43. Ohkawa H, Ohishi N, Yagi K. Assay for lipid peroxides in animal tissues by thiobarbituric acid reaction. Anal Biochem. 1979;95:351-8.

44. Francis D, Rita L. Rapid colorimetric assay for cell growth and surviva modifications to the tetrazolium dye procedure giving improved sensitivity and reliability. J Immunol Methods. 1986;89:271-7.

\section{Submit your next manuscript to BioMed Central and take full advantage of:}

- Convenient online submission

- Thorough peer review

- No space constraints or color figure charges

- Immediate publication on acceptance

- Inclusion in PubMed, CAS, Scopus and Google Scholar

- Research which is freely available for redistribution 